Published on Reviews in History (https://reviews.history.ac.uk)

\title{
Review article on Ulysses S. Grant
}

Review Number: 2270

Publish date: Thursday, 26 July, 2018

Author: Charles W. Calhoun

ISBN: 9780700624843

Date of Publication: 2017

Price: $£ 25.00$

Pages: 720pp.

Publisher: University Press of Kansas

Publisher url: https://kansaspress.ku.edu/978-0-7006-2484-3.html

Place of Publication: Lawrence, KS

Author: Ron Chernow

ISBN: 9781594204876

Date of Publication: 2017

Price: $£ 25.00$

Pages: 1104pp.

Publisher: Penguin Press

Publisher url: https://www.penguinrandomhouse.com/books/311248/grant-by-ron-chernow/9781594204876/

Place of Publication: London

Reviewer: Belle Grenville-Mathers

As a scholar of Grant, I have come to view the news of the publication of each new Grant biography with trepidation. As almost every biographer of Grant has explained at the beginning of their magnum opus, Grant was an extremely complex man whose abilities bemused even his closest friends and allies. He is frequently described as an enigma, and it is clear that he remained an enigma for many of his biographers. However, despite this impenetrability, his reputation has greatly risen over the past two decades, and it rises still with the latest efforts on his life.

Our understanding of Grant, as both a US Civil War General and President, has come a long way since his denunciation by the Dunning School as a callous butcher of soldiers, and an overzealous, incompetent president who forced African-American civil rights on the South. It has changed again since the revisionist portrayal of his presidency as one that abandoned African-Americans as it became engulfed in scandals and corruption - a portrayal that saw Grant's administration ranked as one of the most corrupt in United States History. Estimations of Grant's military capabilities began to rise in the 1950s as historians and popular writers proved that forces under Grant's command suffered fewer casualties than his Confederate counterparts. But the re-evaluation of his presidency has been much slower, beginning in the 1980s and continuing to this day. Increasingly historians are acknowledging that Grant's presidency achieved more and deserves greater praise than previously accorded, especially as he was the last president until Lyndon B. Johnson to make serious efforts to enforce African-American civil rights. This progress is due in great part to the publication of Grant's personal papers by his presidential library (available both in print and online for free), which has led to an explosion of biographies written on both his Civil War career and his presidency. No longer can historians claim, as William B. Hesseltine did in his 1935 biography of Grant's presidency, 
that Grant possesses no manuscript collection.(1) Grant's presidential library has amassed a rich collection of papers for historians to mine, and it is clear that both Charles W. Calhoun and Ron Chernow have benefitted considerably from this resource.

Both authors have produced biographies which present an intelligent, astute politician and man who cared and felt deeply for those less fortunate than himself and who did his utmost within constitutional constraints to prevent violence against southern Republicans from white terrorists. They illustrate that Grant was relatively free from the racism of his day, and tried to treat African-Americans justly both personally and as president. He believed it was the Republican Party's duty to guarantee and protect black civil rights long after his presidency ended. Grant was dedicated to enforcing Reconstruction - more so than many former abolitionists - and his frustration with Congress's inability to legislate on this matter was palpable.

While acknowledging, as many have done before, Grant's personal honesty, they also show that corruption during Grant's presidency was not simply malfeasance but a political weapon wielded to undermine Grant's popularity and his ability to enforce Reconstruction. Though they concede that scandals undermined Grant's presidency, and diverted both Congress's time and attention from Reconstruction, they illustrate that this corruption was well-known and existed long before Grant's administrations. The uncovering of corruption during Grant's second term reflected a desire by many different parties to undermine Grant's reputation.

Yet Calhoun and Chernow have composed two very different biographies. Calhoun's 593-page biography focuses exclusively on Grant's presidency, and his prospects for a third term, and in doing so has filled a gap created by past Grant biographies which have prioritised detailed accounts of Grant's Civil War career to the detriment of his presidency. Calhoun's biography is the more scholarly of the two, and thus the more valuable to Grant's historiography. In contrast, Chernow has followed the traditional biographical route, and written a 959-page analysis of Grant's life, beginning with his ancestry and early life, and ending with the writing of his memoirs. In doing so, he explores every aspect of Grant's life, but he is more balanced than previous biographers as he explores Grant's administrations in greater depth than earlier works have done. His work fits the model of a popular biography, and is a very readable one at that.

Chernow's biography is admirable in many ways, and as a popular biographer he shows how far Grant's reputation has travelled since the historiography of Grant's career began. The Grant in Chernow's biography is intelligent, determined, and dedicated both to the Union and to African-Americans. Chernow highlights how Grant, neither an abolitionist nor a Democrat, disagreed strongly with the institution of slavery and knew the Civil War would lead to its destruction. The book documents Grant's difficult relationship with his father-in-law, which was partly due to their disagreement over the subject of slavery, and which led the latter to refuse to give his daughter the title to her slaves for fear his son-in-law would emancipate them. Later the book shows how enthusiastically Grant supported Lincoln's emancipation and enlistment policies for former slaves, and explains how as president Grant became enraged at white southerners' disregard for the 14th and 15th Amendments, which endowed African-Americans with citizenship and suffrage. Long gone is the indifferent, inept President who failed to protect African-Americans.

Where Chernow really excels is in giving the reader a sense of the man behind the career. His biography is rich in colourful stories which flesh out a so-called 'sphinx' and show Grant to be a cheeky, fearless figure behind the great acts. Chernow recounts playful conversations between Grant and William Sherman, along with reminiscences from other officers about that 'twinkle in Grant's eye that we often saw there when he meant mischief' (p. 348). There are interesting stories too often left out of the scholarly biographies. In one such episode Grant asks to see a defused mine, which is brought to him aboard his naval headquarters, where it started to hiss leading his men to throw themselves onto the deck and jump overboard. He and Admiral Foote run up a ladder before realising their foolishness, leading Foote to ask 'General, why this haste?' to which Grant replies 'That the navy may not get ahead of us' (p. 171). These anecdotes bring Grant to life.

But however endearing these stories make their subject, the numerous contradictions in Chernow's work leave their credibility in doubt. In one instance, he writes of how a servant threw out Grant's false teeth, 
presumably dentures, during the siege of Vicksburg but on two other occasions, one of which is shortly before Grant's death, he writes of Grant's tooth pain resulting in extractions without anaesthesia. Similarly, in an opening chapter Chernow mentions that Grant once commented that he 'never could eat anything that goes on two legs' (p. 15), only to later recount an incident at West Point where an officer called at Grant's room while he was cooking a chicken and commented on the peculiar smell in his room. Unwittingly, what Chernow highlights in these contradictions is the large number of false reminiscences that proliferate about Grant.

Nowhere are these false memories clearer than in Chernow's examination of Grant's supposed alcoholism. One of the main differences between Chernow's biography and previous works on Grant is his thorough exploration of this topic; Chernow considers Grant an alcoholic who learnt to control his addiction, indeed he calls it his greatest battle. Yet, there are numerous contradictory stories in his discussion of Grant's drinking. Various contemporaries claim that once Grant started drinking he could not stop, others suggest that a single drink had a marked effect on him, while yet another acquaintance stated that he used alcohol to calm his nerves. Chernow acknowledges that many recollections of Grant's drinking have clearly been embellished by their authors, who sometimes were not even present when the supposed incidents occurred, but rather than discount the entire story as fiction, he repeatedly writes that there is 'a kernel of truth' in the tale (p. 276). It is a line which he follows even when the stories delineate from his identified pattern of Grant's drinking - alone, in places where he was unknown, and at moments of insignificance. In one incident, he details drunkenness at a dinner in Calcutta during Grant's world tour where the author of the tale is absent having left the city the day before. Chernow substantiates this tale by quoting the words of Grant's brother-in-law, diplomat Michael Cramer, who recalled Grant mentioning that he only drank once on his world tour. Chernow 'wonders' (p. 878) if this tale is the occasion, forgetting that three pages earlier he mentioned Grant having 'a few drops of champagne when the king proposed his health' at a banquet in Copenhagen (p. 875). Similarly, Chernow gives credence to sources, including Union officers, while acknowledging that they were linked to known discontented men who spread slanderous stories of Grant's drinking to the press and to President Lincoln in the hope of promotion above him. It is clear from the numerous anecdotes regarding Grant's drinking that reality blurs with fiction and deducing the truth within is an extremely difficult task.

Most historians agree that there is little concrete evidence to substantiate claims of Grant's drinking during the Civil War. The sources during this era are unreliable, shaped by temperance concerns and partisan and professional rivalries, and many of Chernow's references were written long after the Civil War. The accusations arise from rumours surrounding Grant's resignation from the military in 1854 when he resided in California. Yet no substantial contemporary evidence exists to prove the rumours, and certainly not enough to suggest that leg and foot cramps Grant experienced in California were due to 'alcoholic neuropathy' as Chernow implies (p. 76). What is known, and is evident from Grant's own writing, is that he was greatly unhappy in California and desired to leave the army. It is also known that Grant's military staff during the Civil War contained a man, General John Rawlins, whose own experience with liquor led him to hold Grant to a very high standard, which he frequently accused Grant of missing due to rumours both in print and around the camp. However, Grant claimed several times to have barely touched alcohol during the Civil War even when prescribed it as a remedy for medical illnesses.

But regardless of the justice which Chernow does Grant in other regards, one cannot help but feel that the calls of 'Grant the Musical' which greeted Chernow's biography (Chernow's biography of Alexander Hamilton formed the basis for Lin-Manuel Miranda's critically-acclaimed Hamilton), would result in a production that made Grant's questionable battle with the demon drink the main focus. Its discussion overshadows what is otherwise a readable and entertaining biography of Grant's life, which acknowledges that Grant deserves far greater credit for his presidency than he has been granted.

Calhoun, in contrast, breaks the mould of works that have explored Grant's presidency. In many ways, Calhoun benefits from his position as the first historian to write a biography which focuses solely on Grant's administrations since Hesseltine's 1935 work. However, unlike Hesseltine and his complaints of a lack of 
sources, Calhoun has produced a meticulously researched biography, rich in details and endnotes, which does Grant's administration ample justice. Not only does Calhoun illustrate that Grant was a far more astute man and politician than other biographers have allowed, but he highlights his intellect and political savvy. Calhoun shows Grant's efforts to create a modern presidency, employing a staff to help his efficacy, and applying the same vigour which he showed during the Civil War to achieving his presidential goals. An intensely curious man, Grant involved himself in all aspects of his presidency, only letting his secretaries pursue their own course because he fully supported their endeavours. He made more adroit, informed appointments than historians have recognised, often with an eye to human rights. Indeed, by the end of Grant's presidency, Calhoun asserts that 'Grant himself had become a thorough politician' (p. 535).

By focusing solely on Grant's presidency, Calhoun is able to bring new insights to many aspects of Grant's administrations, such as his cabinet choices, civil service reform, corruption allegations, the attempted annexation of San Domingo, and his third term ambitions. In regard to San Domingo, Calhoun makes an oftmissed point in scholarly works regarding the investigator, Grant's Private Secretary Orville Babcock (incidentally Grant's third preference, chosen in conference with his Secretary of State, Hamilton Fish, who was kept abreast of the president's intentions), sent to the island to explore the desirability of annexation. Although Babcock returned with a Treaty for annexation, this was not Grant's intention, despite the claims of Eric Love.(2) Calhoun also highlights that Charles Sumner, one of the main opponents of annexation, early on appeared supportive of annexation to one of its main supporters, Joseph W. Fabens, an American businessman. Calhoun provides far more detail on the affair than previous scholars and in doing so presents readers with new information on an incident which fractured the Republican Party and undermined Grant's ability to use federal power in reconstructing the South.

But perhaps Calhoun's greatest contribution stems from two interlinked areas: corruption and the enforcement of Reconstruction. Scandals and corruption overshadowed Grant's Reconstruction efforts, thus obscuring Grant's dedication to honesty in government and civil service reform. But Calhoun highlights that often the damaging denunciations came from self-seeking men within Grant's own cabinet, who sought to displace men they disliked or promote their own agendas. Calhoun admits that Grant was not an enthusiastic supporter of civil service reform, but despite this he backed the recommendations of the Civil Service Commission until Congress refused to allocate additional money for their implementation. Grant supported the efforts of his Interior Secretary, Jacob D. Cox, in preventing corruption in his department, but after Cox resigned he wrote a highly critical article on Grant's civil service reforms, which, as Calhoun points out, deviates quite drastically from reality. Historians have long held up Cox's article as an indication of Grant's lacklustre commitment to reform despite Grant's support for Cox, but while Calhoun recognises that Grant made several missteps during his presidency, he believes he remained committed to the nation's prosperity and supported efforts that promoted it.

In Grant's eyes, Reconstruction was another area which promised to boost prosperity, but which was undoubtedly undermined by corruption, both real and imagined. Calhoun shows that though Grant was a committed enforcer of African-American civil rights, he found himself frustrated in his efforts by those within his cabinet. His Treasury Secretary, Benjamin Bristow, after engineering the fall of two Attorney Generals, welcomed the appointment of supporter Edward Pierrepont. Historians tend to blame Grant for retreating from Reconstruction - often claiming he abandoned African-Americans - yet Calhoun points out that although Grant became frustrated with inept southern Republicans, he remained committed to retaining law and order while others in his administration disregarded this necessity in favour of their own political advancement. One such incident occurred before the off-year elections in Mississippi in 1875, when Governor Adelbert Ames requested federal troops to protect the state election after white terrorist groups started a murderous campaign to prevent Republicans from voting. Historians typically portray Grant as unconcerned - pointing out that he resided at his holiday cottage - and dithering over action, which allowed Pierrepont to take charge. However, Calhoun highlights that Pierrepont manipulated the situation providing false information to Grant - to prevent action and protect Republican gains in the Ohio elections, which he believed were crucial for Republican victory in 1876. But, as Calhoun points out, violence from white leagues were too strong. Grant alone could not sustain Reconstruction, and the lack of support Grant 
received from other cabinet members and Congress frustrated his efforts to enforce civil rights.

The Grant that appears in Calhoun's work is a much more effective leader and progressive than other historians have acknowledged, but he is often thwarted by the machinations of office seekers and supposed reformers. He could be 'a powerful legislative leader' (p. 445), who frequently rescued Republicans' legislation when support for their measures wavered, and his 'notions of government action were much broader than the cramped ideas of many Republicans and nearly all Democrats' (p. 400). Grant even pushed a constitutional amendment for public education believing it essential for the future of the nation. In many respects, Grant was a modern president. Yet, in one area Grant remained decidedly non-modern: image crafting. Calhoun believes Grant's downfall lay in his poor image crafting, allowing his deeds to speak for themselves and his enemies to fill in the gaps. But this is not a new assessment, and although Calhoun goes far to show that Grant did his best to prevent corruption, he still leaves the question open as to why it overshadowed Grant's deeds. While there is renewed enthusiasm for Grant's presidential acts, and new insights, Calhoun leaves this question unanswered.

Indeed, in his coda, Calhoun seems to suggest that the efforts of those such as Henry Adams and James Harrison Wilson are to blame for Grant's poor reputation and he wonders whether their potent work can be overcome. Certainly Chernow's book can be seen to show the difficulties inherent in attempts to restore Grant's reputation. While Calhoun writes of the 'Machiavellian purposes of James Harrison Wilson' (p. 149), highlighting his duplicity in his work on Grant, Chernow's work in attempting to substantiate claims of alcoholism with such sources illustrates that Grant's enemies are still afforded the last word on his reputation.

\section{Notes}

1. William B. Hesseltine, Ulysses S. Grant: Politician (New York, NY, 1935), p. vii.Back to (1)

2. Eric T. L. Love, Race Over Empire: Racism and U.S. Imperialism, 1865-1900 (Chapel Hill, NC, 2004), p. 40. Back to (2)

\section{Other reviews:}

Guardian

https://www.theguardian.com/books/2017/dec/06/grant-ron-chernow-review [3]

Sunday Times

https://www.thetimes.co.uk/article/review-grant-by-ron-chernow-jpjrc9v61 [4]

Civil War Talk

https://civilwartalk.com/threads/the-presidency-of-ulysses-s-grant-by-charles-w-calhoun.141668/ [5]

New Yorker

https://www.newyorker.com/magazine/2017/10/02/pour-one-out-for-ulysses-s-grant [6]

Economist

https://www.economist.com/books-and-arts/2017/10/05/todays-historians-have-a-higher-opinion-of-ulysses-

s.-grant [7]

New York Times

https://www.nytimes.com/2017/10/12/books/review/ron-chernow-ulysses-s-grant-biography-bill-clinton.html [8]

Source URL:https://reviews.history.ac.uk/review/2270

\section{Links}

[1] https://reviews.history.ac.uk/item/294629 [2] https://reviews.history.ac.uk/item/299485

[3] https://www.theguardian.com/books/2017/dec/06/grant-ron-chernow-review

[4] https://www.thetimes.co.uk/article/review-grant-by-ron-chernow-jpjrc9v61

[5] https://civilwartalk.com/threads/the-presidency-of-ulysses-s-grant-by-charles-w-calhoun.141668/

[6] https://www.newyorker.com/magazine/2017/10/02/pour-one-out-for-ulysses-s-grant

[7] https://www.economist.com/books-and-arts/2017/10/05/todays-historians-have-a-higher-opinion-of-

ulysses-s.-grant 
[8] https://www.nytimes.com/2017/10/12/books/review/ron-chernow-ulysses-s-grant-biography-billclinton.html 